\title{
PENGARUH QUALITY OF WORK LIFE (QWL) DAN BUDAYA ORGANISASI TERHADAP PRODUKTIVITAS GURU SD SWASTA KATOLIK DI JAKARTA PUSAT
}

\author{
Lucia Klamensia Rahaded*
}

\begin{abstract}
The objective of this research was to understand the effect of Quality Of Work Life $(Q W L)$ and organizational culture on productivity. It was a quantitative research was conducted ten schools located in Jakarta Centre.The research uses a survey method with path analysis was applied in testing hypothesis. It was conducted to 153 teachers at Private Catholic Elementary Schools as the respondents which were selected in a simple random way. The result of this study are: (1). There is a positive direct effect of Quality Of Work Life $(\mathrm{QWL})$ on productivity. (2). There is a positive direct effect of organizational culture on productivity, and (3). There is a positive direct effect of Quality Of Work Life (QWL) on organizational culture.
\end{abstract}

Keywords: Quality Of Work Life $(Q W L)$, organizational culture, productivity.

\section{PENDAHULUAN}

Tantangan terbesar dalam dunia pendidikan di Indonesia pada zaman sekarang ini terletak pada kualitas pendidikan yang sangat memprihatinkan. Problem kualitas pendidikan itu terkait langsung dengan kurangnya sumber daya manusia, dalam hal ini sumber daya guru yang dapat menjadi salah satu sorotan utama ketika produktivitas sebuah sekolah mengalami kemunduran.

Kualitas pendidikan Indonesia yang rendah itu juga ditunjukan data Balitbang pada tahun 2003 bahwa dari 146.052 SD di Indonesia ternyata hanya 8 sekolah saja yang mendapat pengakuan dunia dalam katagori the Primary Years Program (PYP); dari 20.918 SMP di Indonesia ternyata hanya 8 sekolah yang mendapatkan pengakuan dunia dalam katagori the Middle years Program (MYP), dan dari 8.036 SMA ternyata hanya 7 sekolah saja yang mendapatkan pengakuan dunia dalam katagori The Diploma Program (TDP) (http://repository.upi.edu/10785/t pmp_0909896_chapter1). Lebih lanjut berdasarkan hasil Programme for International Student Assessment (PISA) tahun 2012 yang dirilisoleh Organization for Economic Cooperation and Development (OECD) menunjukkan bahwa kemampuan matematika, sains, dan membaca anak Indonesia berada di peringkat bawah yaitu ke-64 dari 65 negara peserta. Kemudian hasil PISA terbaru tahun 2015 seperti yang dilansir oleh BBC Indonesia menunjukkan bahwa Indonesia menduduki posisi ke-69 dari 76 negara peserta (Sean Coughlan, 2016). Sedangkan darihasilstudi TIMSS (Trends in International Mathematics and Science Study), menunjukkan bahwa siswa Indonesia berada pada peringkat 36 dari 49 negara dalam hal melakukan prosedur ilmiah. Dalam 10 tahun terakhir ini hasil PISA dan TIMSS masih berjalan di tempat (Sarnapi, 2016).

*Staf Pengajar di SDNK Duroa 
Rusyan dan Suherian (2012:1) mengatakan bahwa secara formal status guru di dalam budaya Indonesia masih menempati tempat yang terhormat, namun secara material, profesionalisme guru mengalami kemerosotan yang mengkhawatirkan.

Sekolah-sekolah, terutama Sekolah Dasar-Sekolah Dasar Swasta Katolik wilayah Jakarta Pusat mengalami masalah ini. Sumber daya manusia dalam hal ini guru-guru Sekolah Dasar sebagai ujung tombak yang menentukan keberhasilan dalam pendidikan kurang menghasilkan output pendidikan yang dapat menjawab kebutuhan masyarakat. Terkait permaslahan ini, Ketua Tim Kerja Sekolah Dasar Majelis Pendidikan Katolik Wilayah Jakarta Pusat Menginformasikan bahwa: Kurangnya produktivitas guru sekolah Dasar dalam Wilayah Jakarta Pusat telah mengakibatkan berkurangnnya kualitas lulusan SD. Lulusan SD yang kurang berkualitas tersebut telah menyebabkan masyarakat kurang memiliki apresiasi dan beralih memilih menyekolahkan anaknya pada sekolah negeri dan sekolah swasta lainnya. Akibatnya Sekolah Swasta Katolik dalam wilayah Jakarta Pusat mengalami kekurangan murid di tahun-tahun terakhir ini. Indikator dari merosotnya produktivitas guru SD Swasta Katolik dilihat dari masih ditemukan di beberapa guru yang belum bertanggungjawab dalam melaksanakan tugas pokoknya yakni membuat kelengkapan mengajar dengan baik dan lengkap, dalam proses belajar mengajar masih di temukan guru yang belum tepat dalam mencapai tujuan pembelajaran, juga masih sangat kurang dalam menguasai media informasi dan teknologi dalam mewujudkan proses belajar mengajar terutama masih ditemukan guru yang belum tepat dalam menggunakan metode pembelajaran (diperolehdari, Ketua TIM Kerja Sekolah Dasar Majelis Pendidikan Katolik Wilayah Jakarta Pusat, padadesember 2016).

Menurunnya produktivitas guru dipicu oleh beberapa faktor di antaranya adalah Quality of Work Life (QWL) pada guru. Sumber daya manusia merupakan faktor yang sangat berharga, maka kepala sekolah bertanggung jawab untuk memelihara Quality of Work Life (QWL) dan membina guru agar bersedia memberikan kontribusinya secara optimal untuk mencapai tujuan pendidikan. Konsep Quality of Work Life (QWL) mengungkapkan pentingnya penghargaan terhadap manusia dan lingkungan kerjanya. Dengan demikian peran penting dari Quality of Work Life dalam mengubah iklim kerja agar organisasi secara teknis dan manusiawi membawa kepada kualitas kehidupan kerja yang lebih baik. Adanya Quality of Work Life (QWL) yang baik akan menimbulkan semangat para guru untuk bekerja dengan sekreatif mungkin dalam mengajar. Faktor lainnya yaitu budaya organisasi. Budaya organisasi sekolah sebagai suatu sistem nilai memegang peranan yang strategis dalam mengatur mekanisme dinamika organisasi sekolah, maupun kinerja sekolah sebagai pelayanan pendidikan. Budaya yang adaptif berangkat dari logika bahwa hanya budaya organisasi yang dapat membantu organisasi mengantisipasi dan beradaptasi dengan perubahan lingkungan, akan diasosiasikan dengan kinerja yang superior sepanjang waktu. Budaya adaptif ini merupakan sebuah budaya dengan pendekatan yang bersifat siap menanggung resiko, percaya, 
dan proaktif terhadap kehidupan individu. Para guru secara aktif mendukung usaha satu sama lain untuk mengidentifikasi semua masalah dan mengimplementasikan pemecahan yang dapat berfungsi. Ada suatu rasa percaya yang dimiliki bersama yang membangkitkan kegairahan untuk dapat melakukan apa saja untuk mencapai keberhasilan organisasi.

Secara teknis produktivitas digambarkan sebagai perbandingan rasio keluaran (output) dengan masukan (input). Seperti dijelaskan oleh John W. Newstroom (2007:13-14) yang berpendapat bahwa, "Productivity is a ratio that compares units of output with units of input, often againts a predetemined standard. If more outputs can be produced from the same amount of inputs, productivity is improved". Bahwa produktivitas pada dasarnya merupakan rasio antara masukan (input) dan keluaran (output). Hal di atas menegaskan bahwa produktivitas selalu bertumpu pada dua komponen utama yaitu masukan (input) dan keluaran (output). Jika kedua komponen tersebut memiliki besaran yang proporsional, maka hal itu akan dapat dikatakan produktif. Pendapat tersebut menjelaskan bahwa dalam sebuah organisasi itu selalu diusahakan untuk menekan input dan mengoptimalkan output.

Donal C. Mosley, Leon C Megginson, dan Paul H. Pietri (2005:439) yang mengatakan bahwa, "Produktivity is a measure of outputs compared to inputs. Productivity can be increased by increasing output with the same input, decreasing input and maintening the same outputs, or increasing output while decreasing input". Produktivitas adalah ukuran dari keluaran (output) dibandingkan dengan masukan (input). Produktivitas dapat meningkat dengan cara menaikan keluaran dengan masukan yang sama, mengurangi masukan dan menjaga keluaran yang sama, atau menaikan keluaran dengan mengurangi masukan.

Robbins dan Coulter (2012:492) menjelaskan bahwa: Produktivity is the amount of goods or services produced divided by the inputs needed to generate thet output. Organization and individual work units want to be productive. They want to produce the most goods and services using the least input. Output is measured by the sales revenue an organization receives when goods are sold (selling price multiplied by the number sold). Input is measured by the cost of acquiring and transforming resources into outputs. Produktivitas merupakan jumlah barang atau jasa yang dihasilkan dibagi dengan input yang dibutuhkan untuk menghasilkan output yang diinginkan. Dalam memproduksi barang dan jasa tersebut, setiap organisasi atau individu dalam organisasi itu ingin menghasilkan suatu barang atau jasa dengan menggunakan masukan atau input yang serendah-rendahnya.

Ivancevch et.al (2008:26) berpendapat bahwa: Productivity is the relationship between inputs (e.g.,hours of work, effort, use of equipment) and output (e.g.,personal computer productivity such as profit, sales market share, students graduated, patient released, documents processed, client services, and the like. Produktivitas adalah hubungan antara masukan (seperti, jumlah jam kerja, usaha penggunaan peralatan) dan keluaran (seperti produksi, penanganan komplain pelanggan). Ukuran 
produktivitas mencakup profit, penjualan, lulusan siswa, proses dokumen, jasa, pelanggan dan sebagainya.

Robert L Mathis (2011:9) yang mendefinisikan bahwa: Productivity is a measure of the quantity and quality of work done, consedering the cost of the resources used. Productivity can be a competitive advantages because when the costs to produce goods and services are lowered by effective processes, lower prices can be charged or more revenue made. Produktivitas adalah ukuran kuantitas dan kualitas pekerjaan yang dilakukan dengan mempertimbangkanbiaya sumber daya yang digunakan untuk mengerjakan pekerjaan tersebut. Pada konteks ini uraian tersebut mengandung makna bahwa produktivitas merupakan seberapa efektif nilai masukan produk/jasa diolah menjadi sebuah keluaran yang bernilai, dan seberapa efisen penggunaan sumber daya untuk mengolah masukan menjadi sebuah keluaran yang bernilai tersebut dihasilkan.

Rogelberg (2007:651) berpendapat bahwa: Quality of work life (QWL) has been identified as a personal reaction to work environment and experience such as perceptions of control, and well being in relation to someones's job and organizatoin, with no one generally accepted definition of the tern. Dari pernyataan ini Rogelberg memandang bahwa kualitas kehidupan kerja (QWL) diidentifikasi sebagai reaksi personal terhadap lingkungan kerja dan pengalaman seperti persepsi dari kontrol, kepuasan, keterlibatan, komitmen, keseimbangan kehidupan kerja, dan kesejahteraan dalam kaitannya dengan pekerjaan seseorang dan organisasi dengan tidak ada definisi yang berlaku umum bagi istilah tersebut.

Sementara itu Ivancevich, Konopaske, dan Matteson (2008:139) memberikan pandangannya mengenai kualitas kehidupan kerja sebagai berikut, "quality of work life is management philosophy and pratice that enhance employee dignity, introduce cultural chance, and provide oppurtunities for growth and development". Kualitas kehidupan kerja adalah filosofi manajemen dan praktik yang meningkatkan martabat karyawan, memperkenalkan perubahan budaya, dan memberikan kesempatan untuk pertumbuhan dan pembangunan.

Sejalan dengan konsep di atas Cascio (2003:28) berpendapat bahwa: QWL is simple-it involves giving workers the opportunity to make decisions about their jobs, the design of their workplace, and what they need to make products or to deliver services most effectively. It requires managers to treat workers with dignity. Secara sederhana QWL adalah pemberian kesempatan bagi pekerja untuk membuat keputusan tentang pekerjaan mereka, desain tempat kerja dan apa yang mereka butuhkan untuk membuat produk atau memberikan layanan yang paling efektif. Hal itu membutuhkan manager untuk memperlakukan pekerja dengan bermartabat.

Menurut Robert P. Vecchio (2006:378), "in essence, QWL represents a desired and state that emphasized the importance of providing oppurtunities for employees to contribute to their jobs as well as to receive more from their jobs ".Pada intinya QWL mewakili kondisi akhir yang menekankan arti penting memberikan kesempatan kepada 
pegawai untuk ikut membantu pekerjaan serta menerima lebih banyak dari pekerjaan mereka.

Selanjutnya Newstrom (2011:257) menjelaskan QWL adalah: QWL the term refer to the favorableness or unfavorableness of a total job environment for people, QwL programs are another in which organizations recognize their responsibility to develop jobs and working condition that are excellent for people as well as for the economic health of the organization. Program QWL mengacu pada keadaan menyenangkan tidaknya lingkungan pekerjaan bagi orang-orang, QWL adalah salah satu cara dimana mengakui tanggungjawab mereka untuk membangun pekerjaan dan kondisi kerja yang terbaik bagi orang untuk kesehatan ekonomi organisasi.

Edgar H. Schein (2011:71) mendefinisikan budaya organisasi: "a pattern of basic assumptions invented, discovered, or develop by a given group as it learn to cope with its problems of external adaptation and internal integration that has worked well enough to be considered valuable and therefore to be taught to new members as the correct way to perceive, think and feel in relation to those problems". Budaya organisasi adalah sebuah pola asumsi dasar yang ditemukan dan dikembangkan oleh kelompok tertentu seperti belajar mengatasi masalah-masalah adaptasi eksternal dan integrasi internal yang telah bekerja cukup baik untuk dianggap berharga dan karena hal tersebut harus diajarkan kepada anggota baru sebagai cara yang benar untuk melihat, berpikir, dan merasakan keterkaitan dengan masalah-masalah tersebut.

Definisi yang dikemukakan oleh John R. Schermerhorn, James G. Hunt, Richard N. Osborn, Mary Uhl-Bien (2010:12) mengatakan, "organizational culture is a shared set of belief and values within and organization". Budaya organisasi adalah seperangkat keyakinan dan nilai-nilai dalam suatu organisasi.

Joanne Martin (2011:71-72) mendefinisikan budaya organisasi dalam perspektif yang berbeda. Dia mencatat: "as individual come into contact with organizations, they come into contact with dress norms, stories people tell what goes on, the organization's formal rules and procedures, its formal codes of behavior, rituals, task, pay system, jargon, and jokes only understood by insiders, and soon. These elements are some of the manifestations of organizational culture". Sebagai individu yang bersentuhan dengan organisasi, mereka dating berbalut norma-norma, kisah-kisah yang diceritakan orang-orang, aturan formal organisasi dan prosedurnya, kode formal dari perilaku, ritual, tugas-tugas, system pembayaran, jargon, dan lelucon yang hanya dipahami oleh orang dalam, dan segera. Elemen-elemen ini adalah manifestasi budaya organisasi.

Menurut Stephen P. Robbins \& Mary Coulter (2012:52): "organizational culture has been described as the shared values, principles, traditions, and ways of doing things that influence the way organizational members act. In most organizations, these shared values and practices have evolved over time and determine, to a large extent, how things are done around here". Budaya organisasi telah digambarkan sebagai berbagi pengalaman tentang nilai-nilai, prinsip-prinsip, tradisi, dan cara melakukan hal-hal yang dapat mempengaruhi cara anggota organisasi bertindak. Kebanyakan organisasi, berbagi 
pengalaman tentang nilai-nilai dan pada prakteknya telah berevolusi dari waktu ke waktu dan ditentukan sampai batas tertentu, bagaimana hal tersebut dilakukan di sekitar sini.

Steven L. McShane \& Mary Ann Von Glinow (2008:460) mendefinisikan budaya organisasi: "organizational culture is the basic pattern of shared values and assumptions governing the way employees within an organization think about and act on problems and opportunities". Budaya organisasi adalah pola dasar dari kesamaan nilainilai dan asumsi yang mengatur mengenai cara karyawan dalam suatu organisasi dalam berpikir dan bertindak atas permasalahan dan peluang yang ada.

Robert Kreitner(2009:258) mengatakan: "organizational culture is the collection of shared (stated or implied) beliefs, values, rituals, stories, myths, and specialized language that foster a feeling of community among organization members". Budaya organisasi adalah sekumpulan bersama dari (dinyatakan atau tersirat) keyakinan, nilai-nilai, ritual, cerita, mitos, dan bahasa yang dikhususkan untuk menumbuhkan perasaan antaraanggota komunitas organisasi.

\section{METODE}

Penelitian ini dilaksanakan pada SD Swasta Katolik di Jakarta Pusat yang dilaksanakan selama 3 (tiga) bulan. Metode yang digunakan dalam penelitian ini adalah survey dengan menggunakan teknik kausal. Populasi adalah seluruh guru Sekolah Dasar Swasta Katolik di Jakarta Pusat yang berjumlah 248 guru dengan jumlah sampel sebanyak 153 guru. Data yang dikumpulkan dalam penelitian dijaring melalui kuesioner yang berupa skala penilaian (rating scale) dengan sebaran skor antara 1 sampai dengan 5 .

Setelah dilakukan analisis deskriptif dilanjutkan dengan uji persyaratan analisis berupa uji normalitas, uji linearitas data dan keberartian regresi, dilakukan uji hipotesis dengan menggunakan teknik analisis jalur (path analysis).

\section{HASIL DAN PEMBAHASAN}

\section{Pengaruh Langsung Quality of Work Life (QWL) terhadap Produktivitas}

Dari hasil pengujian hipotesis pertama dapat disimpulkan bahwa terdapat pengaruh langsung positif QWL terhadap produktivitas dengan nilai koefisien korelasi sebesar 0,361 dan nilai koefisien jalur sebesar 0,298. Ini memberikan makna QWL berpengaruh langsung positif terhadap produktivitas.

Hasil penelitian ini senada dengan pendapat beberapa ahli di antaranya adalah Schemerhom (2010:38) mengatakan bahwa, "quality of work life is the overall quality of human experience in the workplace".QWL merupakan kualitas keseluruhan dari pengalaman manusia di tempat kerja. Aktivitas manusia dalam bekerja pasti memerlukan sebuah kondisi yang kondusif dalam artian mampu mendorong atau mendukung manusia sebagai karyawan yang produktif.

James L. Gibson (2012:370) memberikan penjelasan mengenai pengaruh QWL terhadap produktivitas sebagai berikut: In some organizations, QWL program are 
intended to increase employee trust, productivity, involvement, retention, and problem solving so as to increase both worker satisfaction and organizational effectiveness. Dalam beberapa organisasi, program QWL dimaksudkan untuk meningkatkan kepercayaan karyawan, produktivitas, keterlibatan, retensi, dan pemecahan masalah sehingga dapat meningkatkan kepuasan pekerja dan efektivitas organisasi.QWL sebagai upaya meningkatkan kondisi lingkungan kerja agar menjadi suasana atau kondisi yang kondusif bagi karyawan dalam bekerja. Upaya meningkatkan QWL yang baik akan berdampak pada peningkatan produktivitas.

Luthans (2011:356) menjelaskan bahwa:QWL may be described as concern about the impact of work on people and organizational effectiveness combined with an emphasis on participation in problem solving and decision making. There is considerable evidence that employees who are truly empowerment and work within a participatory, problem solving, framework are more committed to both the organization and if they are union members to the union. There is research evidence that such high-involvement QWL has a positive impact on employee turnover and productivity, even across cultures. QWL dapat digambarkan sebagai dampak pekerjaan pada orang-orang dan efektivitas organisasi yang kombinasikan dengan partisipasi dalam pemecahan masalah dan pengambilan keputusan. Disebutkan bahwa karyawan yang mengikuti pemberdayaan dan bekerja dengan berpartisipasi lebih serta berkomitmen untuk organissi menunjukan memiliki QWL yang tinggi. Hal itu kemudian berdampak positif pada pergantian karyawan dan produktivitas.

Griffin dan Moorhead (2010:535) juga menjelaskan mengenai manfaat QWL sebagai berikut: "the expected benefits of quality of work life programs are increased emloyee morale, productivity, and organizational effectiveness".Manfaat yang diharapkan dari program QWL yaitu meningkatnya semangat kerja karyawan, produktivitas, dan evektivitas organisasi.

Berdasarkan pernyataan di atas, maka QWL berpengaruh langsungpositif terhadap produktivitas.

\section{Pengaruh Langsung Budaya Organisasi terhadap Produktivitas}

Dari hasil pengujian hipotesis kedua dapat disimpukan bahwa terdapat pengaruh langsung positif budaya organisasi terhadap produktivitas dengan nilai koefisien korelasi sebesar 0,329 dan nilai koefisien jalur sebesar 0,255. Ini memberikan makna budaya organisasi berpengaruh langsung positif terhadap produktivitas.

Hasil penelitian ini senada dengan pendapat beberapa ahli di antaranya adalah Stephen P. Robbins and Timoty A. Judge (2013:567). Depicts Organizational culture as an intervening variable. Employees from an overall subjective perceptions becomes, in effect the organizations culture or personality and affects employee performance and satisfaction. With strongers culture having greater impact. Menggambarkan budaya organisasi sebagai variabel intervening. Karyawan membentuk persepsi subjektif keseluruhan organisasi berdasarkan pada faktor-faktor persepsi keseluruhan 
menjadi pada dasarnya budaya organisasi atau kepribadian dan mempengaruhi kinerja karyawan dan kepuasan. Dengan budaya yang kuat dapat memiliki dampak yang besar. Sikap pekerja dalam sebuah organisasi sangat dipengaruhi oleh lingkungan kerja yang memiliki budaya organisasi masing-masing. Budaya organisasi itu sendiri merupakan suatu hasil interaksi para anggotanya dan merupakan kontribusi dari seluruh elemen yang berada dalam organisasi tersebut. Budaya organisasi yang kuat mampu mempengaruhi tatanan manusia, peralatan, uang, investasi, sumber daya dan barang-barang lainnya yang ada dalam organisasi tersebut untuk mencapai tujuan organisasi. Secara tegas budaya tersebut dapat diserap atau dipaksa diserap oleh anggotanya.

Selanjutnya Ray B. Williams dari University of British Columbia(diakses 29 Juli 2014).The pursuit of happiness has become an important issue for psychologists, economists, and sometimes, politicians. Far from assuming that happiness as a workplace issue and Management strategi. According to Richard Reeves, author of happy Mondays: Putting the Pleasure Back Into Work (link is external), Ed Denier, author of Happiness: Lessons from a New Science, (link is eksternal) and Sonja Lyubomirsky, author of The How of Happiness: a Scientific Approach to Getting the life You Want, (link is external) long-term happiness and life satisfactions is measured by economist from The University of British Columbia presented reasearch on happiness and well-being, based on surveys of more than 100.000 people in Canada and around the word. Among his findings, which have significant implications for the workplace, is that a slight positive increase in a worker's relationship with the boss may translate into a substantial increase in compensation or productivity,

Dari penemuan tersebut dapat disimpulkan bahwa budaya organisasi dapat berpengaruh terhadap produktivitas. Sementara itu produktivitas merupakan hasil karya dan karsa manusia, karena memang dapat dilihat baik dari persepsi seseorang secara individual maupun dari perspektif secara kelompok.

Berdasarkan uraian di atas budaya organisasi pengaruh langsung positif terhadap produktivitas.

\section{Pengaruh Langsung Quality of Work Life (QWL) terhadap Budaya Organisasi}

Dari hasil pengujian hipotesis ketiga dapat disimpulkan bahwa terdapat pengaruh langsung positif QWL terhadap budaya organisasi dengan nilai koefisien korelasi sebesar 0,249 dan nilai koefisien jalur sebesar 0,249. Ini memberikan makna QWL berpengaruh langsung positif terhadap budaya organisasi.

Hasil penelitian ini senada dengan pendapat beberapa ahli di antaranya adalah Linda. et al (2002:442) yang mengungkapkan: Quality of work life program job is one example and development that range organiasasi's culture scope. QWL program create base for management to accept attention and structure that help pengarut's management needs it change bases employ charge. Program kualitas kehidupan kerja adalah sebuah contoh dan pengembangan yang mencakup ruang lingkup budaya organiasasi. Program QWL menciptakan landasan bagi manajemen untuk menerima perhatian 
dan struktur yang membantu manajemen pengarut perlunya perubahan berdasarkan tuntutan pekerja.

Ivancevich (2010:450) memberikan penjelasan bahwa: QWL is utilized widely to refer at one particular management philosophy that increase self-respect all employ as introduces changing deep cultural organisational and fix physical and emotion situation of employee. QWL digunakan secara luas untuk merujuk pada suatu filosofi manajemen yang meningkatkan harga diri semua pekerja seperti memperkenalkan perubahan dalam budaya organisasi serta memperbaiki keadaan fisik dan emosi dari karyawan. Berdasarkan uraian yang dikemukakan di atas Quality of work life (QWL) berpengaruh langsung positif terhadap budaya organisasi.

\section{PENUTUP}

Kesimpulan: Berdasarkan hasil perhitungan data penelitian dan hasil analisis data yang telah diuraikan, maka dapat diperoleh beberapa kesimpulan sebagai berikut: 1) Quality of Work Life (QWL) berpengaruh langsung positif terhadap produktivitas. Artinya, peningkatan Quality of Work Life (QWL) mengakibatkan peningkatan produktivitas guru SD Swasta Katolik di Jakarta Pusat. 2) Budaya organisasi berpengaruh langsung positif terhadap produktivitas. Artinya, peningkatan produktivitas guru dapat dilakukan melalui peningkatan budaya organisasi. 3 ) Quality Of Work Life (QWL) berpengaruh langsung positif terhadap budaya organisasi. Artinya, peningkatan Quality of Work Life (QWL) mengakibatkan adanya perubahan dalam budaya organisasi guru SD Swasta Katolik di Jakarta Pusat.

Saran: Berdasarkan kesimpulan penelitian disarankan berbagai upaya yang dilakukan dalam rangka meningkatkan produktivitas guru SD Swasta Katolik Jakarta Pusat: 1) Bagi Ketua Tim Kerja SD Majelis Pendidikan Katolik (MPK) wilayah Jakarta Pusat, untuk membantu meningkatkan produktivitas guru dengan penerapan peraturan yang ada tanpa pembedaan, serta komunikasi antara kepala sekolah - kepala sekolah dalam forum yang rutin yang dapat menampung aspirasi serta masukan-masukan guna meningkatkan produktivitas guru. 2) Bagi Guru SD Swasta Katolik Wilayah Jakarta Pusat diharapkan dapat meningkatan produktivitas melalui peningkatan kualitas kehidupan kerja serta melaksanakan peraturan yag ada dalam rangka memajukan kemajuan sekolah serta mau dan mampu melakukan perubahan untuk diri sendiri dan kemajuan sekolah yang lebih baik. 3) Bagi para peneliti yang lain, dapat menjadikan penelitian ini sebagai bahan rujukan dalam rangka penelitian yang serupa atau bahkan mengembangkan penelitian ini ke dalam cakupan wilayah penelitian yang lebih luas.

\section{DAFTAR RUJUKAN}

Cascio, Robert P. Vecchio, Organizational Behavior. South Western: Thomson, 2006.

Cascio, Wayne F. Human Resources: Productivity, Quality of Work Life, Profits, Sixth Edition New York: McGrow-Hill Companies,Inc, 2003. 
Gibson L, James et.al. Organizations Behavior, Structure, Processes. New York: McGraw Hill, 2012.

Griffin \& Moorhead, Organizational Behavior Managing People and Organizations,Eleventh Edition. South Western: Cengage Learning,2010.

http://repository.upi.edu/10785/t_ pmp_0909896_chapter1 (diakses 3 november 2014).

https:/ / www.psychologytoday.com/blog/wired-success/201007/how-workplacehappiness-can-boost-productivity (diakses 29 juli 2014).

Informasidiperolehdari, Ketua TIM KerjaSekolahDasarMajelisPendidikanKatolik Wilayah Jakarta Pusat, padadesember 2016.

Ivancevich, Jhon M. Human Resource Management Eleventh Edition. New York: McGraw Hil/Irwin, 2010.

Ivancevich, Konopaske, Matteson, Organizatioal Behavior and Management. New York: McGraw-Hill Companies, 2008.

Luthans, Fred. Organizational Behavior. New York: McGraw Hill, 2011.

Mathis, Robert L. John H. Jaskson, Human Resource Management. SouthWestern:Cengage Learning, 2011.

Mosley, Donald C. Leon C. Megginson, Paul H. Pietri, Supervisory Management. South-Western: Thomson, 2005.

Newstrom, John W. Organizational Behavior, Human Behavior at Work. New York: McGraw-Hill, 2011.

--------. Organizational: Human Behavior at Wok Twelft Edition. New York: McGrawHill/Irwin, 2007.

OECD, "PISA 2012 Result", https://www.oecd.org/pisa/keyfindings/pisa-2012results- overview.pdf(diakses 13 Oktober 2016)

Robbins Stephen P. dan Timothy A Judge, Organizational Behavior Fiteenth Edition. New Jersey: Pearson Education Inc. Publishing as Prentice Hall, 2013.

Robbins, Stephen P. dan Marry Coulter, Management Eleventh Edition. New Jersey: Pearson Prentice Hall, 2012.

Rogelberg, Steven G. Encyclopedia of Industrial and Organizational Pshicology. London: SAGE Publications, 2007.

Rusyan H.A. TabranidanLalanSuherlan, Membangun Guru Berkualitas (Jakarta: PT.GilangSaputra Perkasa, 2012. 
Sarnapi, "PeringkatPendidikan Indonesia MasihRendah",http://www.pikiranrakyat.com/pendidikan/2016/06/18/peringkat-pendidikan-indonesiamasih-rendah-372187(diakses 13 Oktober 2016)

Schermerhorn, John R James G. Hunt, dan Richard N. Osbom, Organization Behavior 11 th Edition. USA: John Wiley \& Sons,2010.

Sean Coughlan, "Asia peringkattertinggisekolah global, Indonesia nomor 69", http://www.bbc.com/indonesia/majalah/2015/05/150513_majalah_asia_se kolah_terbaik (diakses 13 Oktober 2016)

Stroh, Linda. K. Gregory B. Margaret A. Organizational Behavior A Management Challenge. Third edition. New Jersey: Lawrence Erlbawan Associate, Inc. 2002. 